\title{
A AMPLIAÇÃO DA TEORIA DA CAUSA MADURA NOS MOLDES DO CPC/2015
}

THE EXPANSION OF THE THEORY OF MATURE CAUSE IN THE MOLD OF THE BRAZILIAN CODE OF CIVIL PROCEDURE OF 2015

Vinicius Silva Lemos

Advogado. Doutorando em Direito Processual pela UNICAP/PE. Mestre em Sociologia e Direito pela UFF/RJ. Especialista em Processo Civil pela FARO. Professor de Processo Civil na FARO e UNIRON. Coordenador da PósGraduação em Processo Civil da Uninter/FAP. VicePresidente do Instituto de Direito Processual de Rondônia IDPR. Membro da Associação Norte-Nordeste de Professores de Processo - ANNEP. Membro do Centro de Estudos Avançados em Processo - CEAPRO. Membro da Academia Brasileira de Direito Processual Civil - ABDPC. Membro da Associação Brasileira de Direito Processual - ABDPRO. Porto Velho/RO. E-mail: viniciuslemos.ro@gmail.com

RESUMO: Um estudo acerca da Apelação no CPC/2015 e a aplicabilidade do instituto da Teoria da Causa Madura, com a análise da nova sistemática desta forma de julgamento, novas diretrizes, amplificações e alterações. Há também uma inserção dessa possibilidade no Recurso Ordinário e no Agravo de Instrumento contra decisão parcial de mérito. Delinear os impactos doutrinários, reais e práticos dessa ampliação deste instituto, apresentando as inovações e perspectivas de êxito no tocante à Teoria da Causa Madura e sua importância em busca da celeridade processual.

PALAVRAS-CHAVE: Recurso, Causa Madura, Ordinário, Código de Processo Civil de

\footnotetext{
${ }^{1}$ Artigo recebido em 25/05/2019 e aprovado em 31/07/2019.
} 
2015.

ABSTRACT: A study on the recourse in the CPC/2015 and the applicability of the institute of Theory of Cause Mature, analyzing the new systematic this form of trial, new guidelines, amplifications and changes. There is also an insertion in Ordinary Recourse and interlocutory recourse against partial decision of merit. Delineate the impacts doctrinal, real and practical this extension of this institute, introducing innovations and perspectives of success regarding the Theory of Cause Mature and their importance in search to speed up the proceedings.

KEYWORDS: Appeal, Cause Mature, Ordinary, Brazilian Code of Civil Procedure.

\section{INTRODUÇÃO}

Com o advento de novos institutos ou alterações significativas em institutos já existentes, o CPC/2015 deve ser interpretado para a adaptação ao cotidiano doutrinário e forense. Um destes institutos alterados é a teoria da causa madura, com a ampliação de sua incidência e, consequentemente, de sua importância para a fase recursal.

O objeto deste trabalho é justamente a teoria da causa madura, sua relação com os recursos, em especial a apelação, e o entendimento de sua aplicabilidade diante do novo ordenamento processual, bem como a sua ampliação. Primeiramente o entendimento sobre o instituto e a sua própria manutenção no CPC/2015 e, posteriormente, delinear as mudanças dispostas neste novo texto legal que impactam diretamente a teoria da causa madura.

É de grande importância o estudo da seara recursal, principalmente no âmbito de segundo grau, justamente pela relação da teoria da causa madura e o recurso de apelação, delineando o instituto em as suas hipóteses de cabimento, sua utilização e seus moldes, nos detalhes dessa nova formatação disposta.

A preocupação do legislador com a celeridade e a economia processual nos julgamentos recursais de segundo grau concedeu uma maior amplitude à teoria da causa madura, aumentando suas possibilidades, com maior número de hipóteses cabíveis, dada a 
inserção de um leque processual significativa tanto para as partes pleitearem quanto para oficiosamente o Tribunal considerar nos julgamentos das apelações e, eventualmente, agravos de instrumento de decisões parciais de mérito.

Dessa maneira, este trabalho almeja elucidar cada ponto concernente à teoria da causa madura, para um detalhamento material e aumento em sua importância pelo legislador, com ampliação de poderes ao colegiado para julgar, desde logo, o mérito da demanda. Enfrenta-se, ainda, a utilização da teoria da causa madura também no recurso ordinário, uma vez que este recurso tem correlação com os moldes e procedimentos da apelação.

Com todas essas mudanças na teoria da causa madura, pertinente se torna o estudo e a análise de sua incidência, de sua nova roupagem processual e o grau de impacto de suas possibilidades.

\section{DA APELAÇÃO}

A apelação sofreu apenas a mudança no deslocamento de artigos no CPC/2015, antes estava no art. 513 e, agora, foi deslocada para o art. 1.009. Não há alteração sobre a relação do recurso com a sentença, tampouco o que se mudar na conceituação da apelação sobre essa relação, pelo fato de que a redação ${ }^{2}$ do caput do art. 1.009 tem uma redação bem simples: "de sentença cabe apelação".

Se o artigo pertinente à apelação não mudou sua redação, não pode-se falar disso sobre sentença, uma vez que este instituto ampliou sua conceituação, com maior abrangência, conforme molda o art. $203, \S 1^{\circ}$ ao dispor que "sentença é o pronunciamento por meio do qual o juiz, com fundamento nos arts. 485 e 487, põe fim à fase cognitiva do procedimento comum, bem como extingue a execução."

Dessa forma, a nova conceituação de sentença impacta no recurso de apelação, ampliando a possibilidade de impugnação, contudo sem alterar suas características. A sentença, no $\mathrm{CPC} / 73$, detinha uma visão sobre o encerramento do processo de conhecimento como uma definição do instituto, o que somente em parte se mantém essa

2 "Apelação, portanto, é o recurso que se interpõe das sentenças dos juízes de primeiro grau de jurisdição para levar a causa ao reexame dos tribunais do segundo grau, visando a obter uma reforma total ou parcial da decisão impugnada, ou mesmo sua invalidação." THEODORO JR, Humberto. Curso de direito processual civil: teoria geral do direito processual civil e processo de conhecimento. Vol. I. 52. ed. Rio de Janeiro: Forense, 2011. p. 595. 
visão, alterando para o encerramento da fase de conhecimento, não mais do processo, adequando tal sistemática ao processo sincrético, uma vez que será dividido em fases e, consequentemente, a sentença encerra cada uma destas, com diversos encerramentos possíveis no processo.

Quando houver o encerramento da fase de conhecimento, há a prolação de uma sentença; igualmente ocorre quando chegar ao fim da fase de cumprimento de sentença, com uma nova sentença; sem limitação de quantidades de sentenças no mesmo processo, contudo atreladas a cada fase somente.

De qualquer maneira, se houver uma sentença, cabe apelação.

De certo modo, a alteração somente trouxe para a realidade a própria conceituação da sentença, uma vez que a anterior alteração no CPC/73 pela Lei ${ }^{\circ}$ 11.232/2005 imaginou o processo como sincrético, extirpando a execução de título judicial para cumprimento de sentença, uma nova fase dentro do mesmo processo, somente sendo posterior à fase de conhecimento. Dada essa inovação - mantida no CPC/2015 - já concluía-se que a decisão final do cumprimento seria igualmente sentença, mesmo que não estivesse especificado no antigo art. 162.

A novel conceituação de sentença soluciona todas essas dúvidas de decisões e suas relações conceituais, o que facilita o entendimento da natureza jurídica de cada decisão e, consequentemente, do recurso cabível, no caso, apelação, como dita o art. 1.009.

E, ainda, importante salientar que ao dispor que de sentença cabe apelação, evidentemente que em qualquer sentença cabe apelação, independente de seu teor, seja uma sentença de mérito, seja sentença sem mérito, respaldadas pelos arts. 485 (sem mérito) e 487 (com mérito). Portanto, não há uma limitação, tampouco dúvida, sobre as espécies decisórias e, dessa maneira, em qualquer sentença a impugnação será via apelação.

\subsection{Das argumentações e finalidades da apelação}

A apelação, como principal recurso do processo civil, tem enorme abrangência e impacto sobre as discussões dos fundamentos processuais, fáticos e jurídicos da ação, devolvendo-os, quando impugnados, para reapreciação do Tribunal. Cada fundamentação diversa interna do recurso proporciona um pedido diferente na apelação, devendo coadunar cada pedido com cada argumentação existente, criando uma relação condizente de construção impugnativa, com 
uma dialeticidade pertinente.

Dessa maneira, o apelante utiliza a argumentação de error in procedendo ou error in judicando.

$\mathrm{Na}$ primeira hipótese, o error in procedendo ${ }^{3}$ divide-se para a impugnabilidade de qualquer decisão, inclusive da sentença, em duas possibilidades: o vício de formação da sentença (intrínseco); ou o vício processual ou procedimental (extrínseco).

No vício de formação, importante salientar que a sentença tem regras rígidas em sua formação processual criativa, com a necessidade do cumprimento de requisitos formais, tais como relatório, fundamentação e dispositivo e, ainda, outras regras de primordiais, como o respeito ao princípio da adstrição/congruência e a impossibilidade da sentença ser ilíquida quando o autor formular pedido certo e determinado.

No caso de desrespeito a uma dessas possibilidades, há um vício inerente à própria formação da sentença, tornando-a totalmente anulável, de acordo com a extensão do vício no ato judicial. O error in procedendo será interno da sentença, ou seja, intrínseco.

Na segunda hipótese, há um vício de procedimento.

Nesse caso, as impugnações possíveis de suscitação na apelação versam sobre a própria condução processual, a qual o recorrente entende como realizada de modo errôneo ou equivocado pelo juízo, fora dos ditames legais, sem ater-se ao disposto no regramento processual, seja por atuação com supressão de atos, seja por existência de vícios no processo, tais como falta de intimação, não cumprimento do contraditório, dentre tantas outras hipóteses.

O intuito do recorrente é construir o apelo pela necessidade de demonstrar que a regra processual foi tergiversada, com alteração devidamente ilegal e, consequentemente, trazendo prejuízos processuais à parte recorrente.

Comprovado o vício, por via recursal, seja intrínseco, seja extrínseco, justifica-se a invalidação da sentença em grau de apelação pelo colegiado. A consequência da alegação do error in procedendo - qualquer deles - é a necessidade do pedido de anulação da decisão pelo recorrente, não há como alegar esse erro sem culminar no pedido de anulação.

"O erro in procedendo implica em vício de atividade (v.g., defeitos de estrutura formal da decisão, julgamento que se distancia do que foi pedido pela parte, impedimento do juiz, incompetência absoluta) e por isso se pleiteia neste caso a invalidação da decisão, averbada de ilegal, e o objeto do juízo de mérito no recurso é o próprio julgamento proferido no grau inferior”. MOREIRA, José Carlos Barbosa. Comentários ao Código de Processo Civil. 16 a Rio de Janeiro: Forense 2011. p. 267. 
Há uma inter-relação entre error in procedendo e anulação processual.

E, em regra, quando houver a invalidação/anulação da sentença pelo Tribunal, o processo retorna ao primeiro grau para que outra decisão seja proferida (intrínseco) ou para realizar-se o ato suprimido ou sanar o vício do ato processual defeituoso, para após a realização deste novel ato o processo percorrer o caminho restante, ainda em primeiro grau, para a prolação de uma nova sentença (extrínseco).

Quando se alega error in judicando ${ }^{4}$, o mérito é o erro da atividade do julgador quanto ao julgamento dos fatos, quanto a aplicabilidade da lei para o caso em concreto, o real ato de subsunção, mediante sua interpretação entre os fatos e o direito, seja por meio de doutrina, seja por jurisprudência, seja por precedente, seja pela interpretação do texto legal. Em qualquer dessas hipóteses, o recorrente tem o entendimento de que a aquela solução decisória é equivocada para o seu caso e processo, impugnando a decisão com a possibilidade de alegá-la como injusta, como imperfeita para ser a definição meritória daqueles fatos.

A alegação do equívoco recai exatamente sobre a interpretação judicial dada aos fatos ou também sobre a maneira de como os próprios fatos foram decididos, influenciando o direito ali decidido. Ou seja, os próprios fatos, mediante a atividade cognitiva, devem ser definidos diante da busca pela melhor probabilidade de acontecimentos pelas narrativas apresentadas pelas partes, mediante as alegações e as provas postas em juízo, o qual deve definir a questão de fato exposta naquela demanda. Se o juízo define como os fatos serão considerados para a prolação de decisão, logo estes também poderão ser impugnados na sentença, perfazendo, do mesmo modo que as alegações de argumentações jurídicas, um error in judicando.

Com a congruência entre a argumentação e o pedido, há de se pedir, diante do error in judicando, a reforma da decisão, seja para alterar a definição dos fatos da decisão ou os próprios fundamentos jurídicos desta, com a substituição decisória pelo acórdão a ser proferido pelo órgão fracionário ad quem.

O julgamento do error in procedendo sempre precederá ${ }^{5}$ ao do error in judicando,

\footnotetext{
4 “o error in iudicando é resultante da má apreciação da questão de direito (v.g., entendeu-se aplicável norma jurídica impertinente ao caso) ou de fato (v.g., passou despercebido um documento, interpretou-se mal o depoimento de uma testemunha), ou de ambas, pedindo-se em consequência a reforma da decisão, acoimada de injusta, de forma que o objeto do juízo de mérito no recurso identifica-se com o objeto da atividade cognitiva no grau inferior da jurisdição" MOREIRA, José Carlos Barbosa. Comentários ao Código de Processo Civil. $16^{\text {a }}$ Rio de Janeiro: Forense 2011. p. 267.

"Antes de julgar o mérito, deverá o relator (ou o órgão colegiado respectivo, cf. § 4. ${ }^{\circ}$ do art. 938 do
} 
pelo fato de que o êxito do primeiro pode impossibilitar, por vezes, o julgamento da segunda argumentação. Se o juízo entender que há vícios processuais - intrínsecos ou extrínsecos - não há motivos para adentrar-se nas questões jurídicas de fundo da demanda, com a anulação da decisão ou de parte do processo, com a volta deste para um ponto procedimental anterior, sem a necessidade de análise sobre o mérito oriundo do error in judicando, o que restou como prejudicado pelo provimento do error in procedendo.

\subsection{Da inserção da teoria da causa madura no ordenamento brasileiro}

O CPC/73 continha em seu art. $515, \S 3^{\circ 6}$ a possibilidade do Tribunal afastar questões processuais proferidas em sentença terminativa - as decisões sem exame do mérito - e, em caso de provimento do recurso nesta parte terminativa, com a retirada daquele vício meramente processual, se na demanda restasse somente matéria de direito e o processo estivesse pronto para julgamento, poderia proceder com o julgamento da demanda em segundo grau, sem a necessidade de determinação de remessa ou volta do processo para ao primeiro grau.

Se houvesse uma possibilidade de julgamento direto no Tribunal, sem qualquer ato a ser realizado, não era necessária a remessa do processo de volta ao juízo a quo, decidindo, desde já, o mérito do processo. A teoria da causa madura permitia, dada a sua inclusão no ordenamento, que um processo fosse decidido somente com um pronunciamento de segundo grau, uma vez que a sentença era somente sem mérito, sem decisão sobre as questões meritórias do processo $^{7}$.

CPC/2015) identificar se há alguma questão preliminar a ser resolvida (sobre questões prévias, preliminares e prejudiciais, cf. comentário ao art. 489 do CPC/2015). Não se conhecerá do mérito, caso sua análise seja incompatível com o que se tiver decidido, em relação à questão preliminar. Deve-se, porém, antes de se não se conhecer do recurso (juízo de admissibilidade negativo), verificar se sua correção ou o saneamento de outro vício processual que impeça o exame do mérito é possível (cf. comentário a seguir). Rejeitada a preliminar ou não sendo ela incompatível com o mérito, seguir-se-á o julgamento, com o exame da questão principal (cf. art. 939 do CPC/2015)." MEDINA, José Miguel Garcia. Novo código de processo civil comentado. $2^{\text {a }}$ Edição. RT: São Paulo. 2015. p. 836.

6 CPC/73 - Art. 515. A apelação devolverá ao tribunal o conhecimento da matéria impugnada. (...) $\S 3^{\circ}$ Nos casos de extinção do processo sem julgamento do mérito (art. 267), o tribunal pode julgar desde logo a lide, se a causa versar questão exclusivamente de direito e estiver em condições de imediato julgamento. (Incluído pela Lei $\mathrm{n}^{\circ} 10.352$, de 26.12.2001).

7 "Com a nova regra, mesmo que a sentença tenha sido terminativa, o efeito devolutivo da apelação permitirá ao tribunal julgar o mérito da causa, desde que satisfeitos dois requisitos: a) se a causa versar 
Revista Eletrônica de Direito Processual - REDP.

Rio de Janeiro. Ano 13. Volume 20. Número 2. Maio a Agosto de 2019

Periódico Quadrimestral da Pós-Graduação Stricto Sensu em Direito Processual da UERJ

Patrono: José Carlos Barbosa Moreira (in mem.). ISSN 1982-7636. pp. 339-366

www.redp.uerj.br

$\mathrm{O}$ intuito de existência dessa possibilidade passa pela necessidade de celeridade processual $^{8}$, por se almejar uma duração razoável do processo, princípio primordial para o processo civil no sentido de busca em garantir eficiência.

O Tribunal, nessa hipótese, está julgando um recurso de um processo que impugna uma decisão sem mérito, afastando o vício que o juízo a quo fundamentou como existente para encerrar o processo, com a possibilidade aberta para que o colegiado, desde logo, continuar o julgamento numa nova fase, ultrapassando o vício outrora existente e alcançando o mérito da demanda ${ }^{9}$. Entretanto, para que seja possível a utilização da teoria da causa madura há a necessidade de que o processo esteja pronto para julgamento, sem a necessidade ou imprescindibilidade de nenhum ato a ser realizado pelo juízo a quo ${ }^{10}$.

Sem a necessidade de produção probatória sobre a questão de fundo da demanda ou qualquer outro ato processual impeditivo de julgar o mérito, o Tribunal deve julgar a demanda, mesmo que isso resulte no primeiro pronunciamento de mérito naquela ação, justamente pela eficiência processual. O processo deve estar em condições de imediato julgamento, sem nenhuma dificuldade probatória para tanto, não podendo significar nenhum prejuízo às partes.

sobre questão exclusivamente de direito; e b) o feito estiver em condições de imediato julgamento (um recurso contra indeferimento da inicial, por exemplo, não pode ser apreciado pelo mérito da causa, porque ainda não se realizou o contraditório; assim, também quando a extinção se deu na fase de saneamento, sem que ainda se pudesse ter o contraditório completo). Não basta, portanto, que a questão de mérito a decidir seja apenas de direito; é necessário que o processo esteja maduro para a solução do mérito da causa" THEODORO JR. Humberto. Curso de direito processual civil: teoria geral do direito processual civil e processo de conhecimento. Vol. I. 52. ed. Rio de Janeiro: Forense, 2011. p. 661/662.

8 "Essa inovação atende ao desiderato de acelerar a outorga da tutela jurisdicional, rompendo com um histórico e prestigioso mito que ao longo dos séculos os processualistas alimentam sem discutir. Não há por que levar tão longe um princípio, como tradicionalmente se levava o do duplo grau nos termos em que ele sempre foi entendido, quando esse verdadeiro culto não for indispensável para preservar as balizas do processo justo e équo, fiel às exigências do devido processo legal." DINAMARCO, Cândido Rangel. A reforma da reforma. São Paulo : Malheiros, 2002. p. 152.

9 "Também se opera o efeito translativo da apelação (desde que a causa esteja "madura", isto é, em condições de receber imediato julgamento) quando o tribunal, na apreciação da apelação, decreta a nulidade da sentença por não ser ela congruente com os limites do pedido ou da causa de pedir (ou seja, se a sentença for extra petita, nos termos do art. 1.013, § 3o, II)." CÂMARA, Freitas, A. (01/2017). $O$ Novo Processo Civil Brasileiro, $3^{a}$ edição. [Minha Biblioteca]. Retirado de https://integrada.minhabiblioteca.com.br/\#/books/9788597009941/

10 "Manteve, no $\S 3^{\circ}$, a expressão: se a causa estiver em "condição de imediato julgamento". Deve-se entender, por essa expressão, a situação de o mérito ter sido discutido pelas partes em primeiro grau de jurisdição - ou, pelo menos, de se ter verificado o contraditório - a ponto de ser possível identificar, com clareza, qual é o quadro fático sobre o qual se funda o pedido. O mesmo não se verifica, contudo, quando não tiver ocorrido o contraditório.” WAMBIER, Teresa Arruda Alvim; CONCEIÇÃO, Maria Lúcia Lins; RIBEIRO, Leonardo Ferres da Silva; MELLO, Rogério Licastro Torres de. Primeiros comentários ao novo código de processo civil. 1'. Ed, São Paulo: RT. 2015. p. 1.450. 


\subsection{O efeito desobstrutivo e o julgamento da matéria de fundo da ação}

Se os requisitos estiverem presentes naquele processo, com a desobstrução do vício anteriormente existente, desnecessário se faz remeter para o juízo inferior para a prolação de uma outra sentença e, posteriormente, ser cabível novamente um recurso de apelação para rediscutir essa "nova sentença", agora de mérito.

Ao permitir que o órgão fracionário julgue o mérito, nessa hipótese, economiza-se tempo ao processo, justamente para impedir que haja uma remessa de retorno ao juízo inferior e uma possível interposição de recurso para o Tribunal, com tanto tempo para ir ao primeiro grau e voltar em eventual recurso de apelação, demoraria o processo para sua devida resolução, muito mais tempo do que o órgão fracionário poder já julgar o mérito daquele recurso em que o processo encontra-se apto para tal desiderato.

Ao julgar a sentença terminativa, ultrapassando essa parte, convém ao órgão fracionário realizar o julgamento do mérito.

O motivo que se autoriza essa excepcionalidade está na possibilidade daquele processo estar pronto para ser julgado em seu mérito, naquele momento recursal, somente com a necessidade da conjunção com o provimento recursal pela mudança da sentença terminativa, com a supressão do vício outrora existente.

Com isso, o processo está maduro para ser julgado e resolvido, com a devida prestação jurisdicional naquele momento, pronto para a decisão da questão meritória, concedendo a doutrina a especificação de teoria da causa madura para essa possibilidade ${ }^{11}$.

Pela possibilidade da teoria da causa madura, abre-se um efeito diferente ao recurso, que não é o devolutivo, pelo fato deste somente devolver a matéria sobre a sentença terminativa. A parcela sobre o pedido posterior pela análise do mérito não contém devolução, mas um pedido de julgamento pela primeira vez no processo, pelo fato de que não fora ainda prestada jurisdição na esfera meritória.

Dessa forma, a apelação serviria como um efeito desobstrutivo, com o provimento do recurso para afastar a sentença terminativa - e o vício impeditivo existente, com a devida

11 "Na verdade, quando o tribunal aprecia o objeto de uma causa, sem que o a quo o tivesse feito, de forma total ou parcial, não está propriamente julgando o recurso, mas sim fazendo o que o juízo inferior faria se os autos lhes fossem devolvidos.” LOPES Jr.. Gervásio. Julgamento direto do mérito na instância recursal. Salvador: Editora Jus Podivm, 2007. p. 36. 
Revista Eletrônica de Direito Processual - REDP.

Rio de Janeiro. Ano 13. Volume 20. Número 2. Maio a Agosto de 2019

Periódico Quadrimestral da Pós-Graduação Stricto Sensu em Direito Processual da UERJ

Patrono: José Carlos Barbosa Moreira (in mem.). ISSN 1982-7636. pp. 339-366

www.redp.uerj.br

desobstrução do processo para a prolação de uma decisão de mérito, desde logo ${ }^{12}$.

O julgamento proferido na teoria da causa madura detém cunho além da sua forma recursal $^{13}$, justamente por ao se julgar pelo provimento do recurso para afastar o vício que impossibilitava o juízo a quo de adentrar no mérito acaba o viés recursal do julgamento, o objeto de impugnação daquela uma decisão e o motivo de julgamento. A partir deste momento, o julgamento passa, ainda que pelo colegiado e diretamente no Tribunal, a ser realizado pela primeira vez, como uma autêntica competência originária, de maneira excepcional.

\subsection{A teoria da causa madura e a possível ofensa ao princípio do duplo grau de jurisdição}

A teoria da causa madura possibilita ao juízo ad quem se julgar pelo provimento do recurso, além do julgamento da matéria recursal adentrar-se no mérito da causa, nunca dantes julgada nesta demanda. O intuito é possibilitar uma maior celeridade ao impedir um "vai e volta" do processo do Tribunal para o primeiro grau e, posteriormente, novamente ao Tribunal numa possível segunda apelação.

Se o Tribunal diante de uma matéria possível da utilização da teoria da causa madura pode julgar, desde logo, o mérito da demanda, não há motivos de criar embaraços processuais com a remessa para o primeiro grau, consistindo no dever de julgar o mérito.

Por outro lado, há um julgamento de forma originária, a parte que tiver o prejuízo da decisão meritória realizada pelo colegiado não terá o direito de uma recorribilidade nos moldes recursais da apelação, sem a possibilidade do duplo grau de jurisdição, por ser realizado diretamente pelo Tribunal.

Posto isto, é pertinente a seguinte indagação: há uma ofensa ao princípio do duplo

12 “O julgamento do mérito diretamente pelo tribunal não é consequência do efeito devolutivo do recurso, até porque ele ocorre após o julgamento do recurso - é um outro efeito da apelação, já denominado efeito desobstrutivo do recurso." CUNHA, Leonardo José Carneiro da; DIDIER JR., Fredie. Curso de direito processual civil. Meios de impugnação às decisões judiciais e processo nos tribunais. $13^{\mathrm{a}}$ ed. Salvador: JusPodivm, 2016. p. 194.

13 "Diante da nova perspectiva legislativa há ampliação dos poderes decisórios dado ao tribunal de apelação, que já era o competente para enfrentar o meritum diante de uma sentença definitiva, nada mais fazendo que abreviar o procedimento, atendendo à efetividade, celeridade e economia processuais." GUIMARÃES PESSOA, FLÁVIA M; ESMERALDO, A. M.. Teoria da Causa Madura e o duplo grau de jurisdição no novo código de processo civil. Revista Eletrônica de Direito Processual , v. 15, p. 1952012, 2015. p. 210. 
Revista Eletrônica de Direito Processual - REDP.

Rio de Janeiro. Ano 13. Volume 20. Número 2. Maio a Agosto de 2019

Periódico Quadrimestral da Pós-Graduação Stricto Sensu em Direito Processual da UERJ

Patrono: José Carlos Barbosa Moreira (in mem.). ISSN 1982-7636. pp. 339-366

www.redp.uerj.br

grau de jurisdição pela utilização da teoria da causa madura? Evidente que $\operatorname{sim}^{14}$, não há um recurso que ataque esta decisão de mérito prolatada somente pelo Tribunal, mesmo possível um recurso especial ou extraordinário, estes têm a necessidade da existência da questão federal ou constitucional, sem um caráter automático. Ou seja, a parte prejudicada pela decisão de mérito da teoria da causa madura não terá um recurso nos moldes da apelação para a impugnabilidade da primeira decisão no processo sobre o mérito.

O importante sobre a relação teoria da causa madura $x$ duplo grau de jurisdição passa pela necessidade de visualizar a real importância deste princípio e possibilidade de sua relativização. O princípio do duplo grau de jurisdição pode ser relativizado? Sem problemas, até pelo fato de que a ofensa a este princípio está na busca pela melhor técnica processual, sem causar prejuízo imenso às partes, uma vez que estas terão um julgamento diretamente pelo Tribunal, com a análise de todos os pontos do processo, numa matéria somente de direito sem a necessidade de produção de provas $^{15}$.

Ao mesmo tempo em que se contraria este princípio, se fundamenta que essa contrariedade não fere a legalidade da utilização da teoria da causa madura, justamente pela ampla possibilidade de tergiversação do princípio em prol da economia e celeridade processual.

\subsection{O julgamento em causa madura como dever de ofício ou como resposta a requerimento?}

Entretanto, uma indagação é pertinente para a utilização da teoria da causa madura: é necessário - ou requisito - que a apelação contenha pedido no sentido do julgamento do mérito da ação, para a possibilidade em que o pedido anterior sobre a sentença terminativa

14 "Segundo pensamos, o $\S 3^{\circ}$ do art. 515 não viola a Constituição Federal. Como se viu, o princípio do duplo grau de jurisdição não é garantia constitucional. Essa concepção, no entanto, como se mencionou, não é pacífica, havendo defensores de orientação contrária. Para estes, muito provavelmente o $\S 3^{\circ}$ do art. 515 do CPC deverá ser considerado inconstitucional. $\mathrm{O}$ fato de não estar diante de inconstitucionalidade, contudo, não torna, só por isso, menos criticável o preceito, porquanto nos casos em que, em atenção ao $\S 3^{\circ}$ do art. 515 do CPC, o tribunal - ou o relator sozinho (cf. art. 557 do CPC) - julga questão de mérito que não havia sido sequer examinada pelo juízo $a$ quo, estará realizando julgamento que só excepcionalmente poderá vir a ser reapreciado." MEDINA, José Miguel Garcia. Aspectos Polêmicos e Atuais dos Recursos e outros meios de impugnação às decisões judiciais, Editora Revista dos Tribunais, São Paulo, 2002. p. 342/343.

15 A nova regra processual possibilita o julgamento diretamente pelo tribunal quando a causa estiver em "condições de imediato julgamento". Isso amplia o alcance do dispositivo, já que não se limita à "matéria exclusivamente de direito". JÚDICE, Monica. Comentário ao art. 1.013. STRECK, Lenio. (3/2016). Comentários ao código de Processo Civil, 11 ${ }^{a}$ edição.. [Minha Biblioteca]. Retirado de https://integrada.minhabiblioteca.com.br/\#/books/9788502635609/ 
Revista Eletrônica de Direito Processual - REDP.

Rio de Janeiro. Ano 13. Volume 20. Número 2. Maio a Agosto de 2019

Periódico Quadrimestral da Pós-Graduação Stricto Sensu em Direito Processual da UERJ

Patrono: José Carlos Barbosa Moreira (in mem.). ISSN 1982-7636. pp. 339-366

www.redp.uerj.br

seja provido? Essa resposta é complexa, justamente pelo dispositivo autorizante especificar como um dever do Tribunal e, não uma faculdade, construindo uma visualização do colegiado cumprir o seu dever jurisdicional quando enquadrar-se nessa situação processual material.

Cunha e Didier Jr. entendem que o Tribunal somente assim deve proceder se houver requerimento para tanto ${ }^{16}$, ainda que haja o enquadramento naquela situação. E, ainda, entendem que existente tal pedido dentre os pedidos recursais, a questão deve ser analisada, imbuindo o colegiado do dever de enfrentar o enquadramento ou não na teoria da causa madura. Então, constroem o entendimento que em modo inverso, sem a existência de pedido para julgamento do mérito da ação em caso de provimento do recurso para a retirada do vício, o Tribunal, ao adentrar-se em questões não requeridas na peça recursal, proferiria acórdão incongruente com o pedido feito no recurso.

No entanto, de modo diverso do construído por Cunha e Didier Jr., há um evidente dever do colegiado ${ }^{17}$, uma vez que o art. $1.013, \S 3^{\circ}$ estipula que o Tribunal deve decidir o mérito, de um modo que a norma processual não concede discricionariedade e, ainda, importa em uma sapiência das partes sobre tal desiderato, uma vez que todos conhecem a norma processual e devem entender pela própria previsibilidade legal dentro do recurso de apelação.

Ou seja, quando houver tal recurso com enquadramento em situações específicas da norma processual em questão - a possibilidade de desobstrução do vício, a utilização da teoria da causa madura é efeito subsequente, sem a necessidade de requerimento ou escolha do recorrente, como prerrogativa do próprio colegiado. As partes - recorrente e recorrida - já estão cientes de tal possibilidade, caso enquadrável nessa configuração processual.

16 “Assim, para que seja aplicada a regra do $\S 3^{\circ}$ do art. 1.013 do CPC, é preciso que o recorrente, em suas razões recursais, requeira expressamente que o tribunal dê provimento à apelação e, desde logo, aprecie o mérito da demanda. Caso o apelante requeira que, após o provimento do recurso, sejam os autos devolvidos ao juízo de primeira instância para análise do mérito, não poderá o tribunal, valendo-se do § $3^{\circ}$ do art. 1.013 do CPC, adentrar o exame do mérito, sob pena de proferir decisão extra petita. Caso o apelante requeira que o tribunal, provendo seu recurso, já aprecie o mérito, ai sim cabe ao tribunal, obrigatoriamente, proceder a análise do mérito, sob pena de a decisão ser citra petita. Nesse caso, o tribunal apenas deixará de apreciar o mérito, se o processo não estiver em condições de imediato julgamento. Vale dizer que, havendo requerimento expresso do apelante, e preenchidos os demais pressupostos legais, é obrigatório ao tribunal, aplicando o $\S 3^{\circ}$. do art. 1.013 do CPC, já conhecer do mérito da demanda." CUNHA, Leonardo José Carneiro da; DIDIER JR., Fredie. Curso de direito processual civil. Meios de impugnação às decisões judiciais e processo nos tribunais. $13^{\mathrm{a}}$ ed. Salvador: JusPodivm, 2016. p. 195.

17 OLIVEIRA, Pedro Miranda de. Novíssimo Sistema Recursal conforme o CPC/2015. Florianópolis: Conceito Editorial, 2015. p. 109. 
Desse modo, quando o colegiado desobstruir o acórdão viciado reabre a matéria para um novel julgamento, mesmo sem requerimento do recorrente, adentrando em questões meritórias da demanda, sem proferir um acórdão inadequado ou equivocado, mas de acordo e nos moldes dos ditames legais, uma vez que o colegiado detém total liberdade, pela previsão legal expressa, para já julgar o mérito da demanda ou, se entender pertinente e necessário, remeter ao primeiro grau, caso não configurada a possibilidade da teoria da causa madura.

Não há necessidade de requerimento para que se utilize a teoria da causa madura e o efeito desobstrutivo. No entanto, se o apelante pleitear o julgamento de mérito, de modo subsequente ao provimento da apelação, o colegiado terá que analisar tal ponto, com total liberdade sobre a escolha de mandar novamente para o primeiro grau ou julgar o mérito, mas somente se houver a configuração dos requisitos da teoria da causa madura. Se houver o pleito no recurso há uma vinculação sobre a análise, ainda que não seja para prover o recurso sobre tal ponto, sendo possível o Tribunal optar pela remessa ao primeiro grau para completar, processualmente, a demanda, sem a configuração dos requisitos necessários para o julgamento meritório diretamente no Tribunal.

\section{AMPLIAÇÃO DA TEORIA DA CAUSA MADURA}

No $\mathrm{CPC} / 2015$, o art. 1.013, $\S 3^{\circ}$ versa sobre as matérias possíveis de serem devolvidas para um novel julgamento sobre o mérito, quando, positivamente, realizar-se a análise dos vícios processuais. As hipóteses da aplicação da teoria da causa madura estão estipuladas no dispositivo acima exposto, primeiramente replicando a mesma do CPC/73, na sentença terminativa, contudo inovando com o acréscimo de outras situações legais para tanto, ampliando ${ }^{18} \mathrm{o}$ alcance do próprio instituto da causa madura na apelação, concedendo maior probabilidade, adequação e viabilidade do instituto.

$18 \mathrm{O} \S 3^{\circ}$ do art. 1.013 cuida da aplicação da chamada teoria da causa madura, que já frequentava o código revogado no $\S 3^{\circ}$ do art. 515. O legislador considerou a necessidade de duração razoável do processo (art. $5^{\circ}$, LXXVIII, da CF), e daí permitiu que mesmo nos casos em que (I) a sentença seja só terminativa (art. 485), ou (II) padeça de nulidade por desbordar dos limites da postulação, ou seja (III) "citra petita", ou (IV) nula por falta de fundamentação, o tribunal deverá decidir desde logo o mérito da causa (e daí também a lembrança do princípio da primazia da decisão de mérito - art. $4^{\circ}$ do CPC)." NASCIMENTO NETTO, Marcos Aurélio. Comentário ao art. 1.013. Novo Código de Processo Civil Comentado - Tomo III. Orgs: RIBEIRO, Sergio Luiz Almeida; GOUVEIA FILHO, Roberto Pinheiro Campos; PANTALEÃO, Izabel Cristina; GOUVEIA, Lucio Grassi de. Ed. Lualri,São Paulo, 2017. p. 364. 
Revista Eletrônica de Direito Processual - REDP.

Rio de Janeiro. Ano 13. Volume 20. Número 2. Maio a Agosto de 2019

Periódico Quadrimestral da Pós-Graduação Stricto Sensu em Direito Processual da UERJ

Patrono: José Carlos Barbosa Moreira (in mem.). ISSN 1982-7636. pp. 339-366

www.redp.uerj.br

As outras hipóteses de aplicação da teoria em questão, além daquela de sentença terminativa, estão no mesmo parágrafo citado ${ }^{19}$ do art. 1.013, as quais delineia-se a seguir: falta de congruência da sentença com os pedidos da petição inicial; omissão na sentença sobre um dos pedidos realizadas na petição inicial; nulidade da sentença por falta de fundamentação baseada no art. 489, § 1º ; a última, nesse caso baseada no art. 1.013, § $4^{\circ}$, quando uma apelação impugna uma sentença em que se reconheceu a decadência ou a prescrição e consegue-se o efeito desobstrutivo.

É pertinente o enfrentamento de cada uma das hipóteses pormenorizadamente.

\subsection{Apelação que julga a sentença terminativa prolatada com base no art. 485}

Essa hipótese é aquela que já era positivada no ordenamento processual anterior, com a possibilidade de decisão de mérito, desde logo, quando a sentença fosse meramente terminativa e houvesse o provimento do recurso de apelação. Por sentença terminativa entende-se aquela que não enfrenta o mérito, ou seja, o pedido que o autor realiza na inicial, aquele que se espera ser definido na prestação jurisdicional. Uma decisão sem a resposta jurisdicional com a matéria do objeto litigioso do processo.

No decorrer da demanda, se houver qualquer dos vícios elencados no art. 485, o juízo deve julgar extinta a demanda, sem o enfrentamento do mérito, sem o pedido realizado na petição inicial ser devidamente enfrentado, sem a solução daquele conflito de interesses, com uma decisão que responde ao jurisdicionado que não há como, processualmente, responder aquela pretensão material.

19 "Não é o caso, assim, de deixar de pronunciar a nulidade. Na verdade, a questão é que, mesmo anulando a sentença, não serão os autos mais remetidos à instância originária, podendo o tribunal, desde logo, apreciar o meritum causae. A questão, repita-se, diz respeito à supressão de uma instância em favor de se obter um julgamento definitivo em menor espaço de tempo. É importante ter em vista a necessidade de que, efetivamente, a nulidade seja pronunciada pelo tribunal ad quem nestes casos até mesmo em observância à correta técnica de julgamento nos órgãos colegiados. Parece-nos que, para aplicar o disposto no art. 1013, $\S 3^{\circ}$., IV, do Novo CPC (como, mutatis mutandis, todas as demais hipóteses de "causa madura"), o tribunal deve, antes de tudo, (i) anular a sentença por deficiência de fundamentação. Posteriormente, deve haver nova deliberação a respeito (ii) da possibilidade de julgamento imediato do mérito, pela desnecessidade da produção de outras provas e, em caso positivo, (iii) devem os julgadores, finalmente, proceder à análise do meritum causae." SIQUEIRA, Thiago Ferreira. A aplicação da "teoria da causa madura" em caso de nulidade da sentença por falta de fundamentação: um diálogo com Marco Antonio Perez de Oliveira. http://portalprocessual.com/aaplicacao-da-teoria-da-causa-madura-em-caso-de-nulidade-da-sentenca-por-falta-de-fundamentacao-umdialogo-com-marco-antonio-perez-de-oliveira/ 
Desse modo, no caso de apelação protocolada para impugnar a existência desse vício processual, se esta for provida com decisão de conteúdo pelo afastamento deste vício e a configuração da possibilidade de julgamento imediato da matéria meritória, não há motivos para a devolução da demanda para o primeiro grau, com o enfrentamento direto pelo Tribunal de segundo grau, como uma profundidade da devolução da apelação.

\subsection{Nulidade da sentença por ser incongruente}

Quando o Tribunal decretar a nulidade da sentença por ser incongruente com o limite do pedido e a causa de pedir caberá ao colegiado, desde logo, enfrentar o mérito da ação no julgamento dessa apelação.

Nessa hipótese, a decisão recorrida fugiu dos limites da formalidade do próprio ato da sentença, com uma evidente violação ao princípio da congruência/adstrição do ato judicial decisório, uma vez que os limites impostos no momento do pedido inicial foram ultrapassados na decisão, pelo fato de que o juízo não se satisfez em somente responder os pedidos requeridos na exordial versando também sobre matérias que não constavam na própria lide, seja para ultrapassar o limite, seja para inserir um ponto decisório estranho ao que fora pedido.

Em qualquer deles, seja matéria que ultrapasse, seja estranha à inicial ${ }^{20}$, o vício está na formalidade da sentença, necessitando esta ser anulada e, se o processo estiver pronto para o julgamento de mérito, por estar vencida a fase de produção de provas, ao decretar a nulidade da sentença pelo julgamento da apelação o colegiado pode adentrar-se na análise do mérito da demanda, uma vez que há o cumprimento do requisito de estar apto para tal julgamento, faltando-lhe, após o efeito desobstrutivo, somente a matéria de direito a ser aplicada na análise meritória, podendo valer-se da teoria da causa madura.

No entanto, pertinente verificar se há o que ser decidido ainda.

Na sentença extra petita, temos duas alternativas: um pedido estranho no meio de pedidos da demanda; ou um pedido estranho no lugar dos pedidos da demanda.

20 "Na sentença ultra petita, o juiz concede ao autor a tutela jurisdicional pedida, o gênero do bem da vida pretendido, mas extrapola a quantidade indicada pelo autor." "A sentença extra petita é tradicionalmente considerada como a sentença que concede algo diferente do que foi pedido pelo autor. " NEVES, Daniel Amorim Assumpção. Manual de direito processual civil. 8. ed. Volume único. Salvador: JusPodivm, 2016. p. 1.084/1.085. 
Na primeira hipótese, não há a teoria da causa madura, pelo fato de somente se extirpar aquilo que foi extra na sentença, contudo, na segunda hipótese retira-se o que não tem congruência e, depois com a ausência de decisão sobre determinado ponto pleiteado na petição inicial daquela demanda passa-se para a aplicação da teoria da causa madura.

$\mathrm{Na}$ sentença que julga além do pedido, o que seria configurado ultra petita, caberia a teoria da causa madura? Essa indagação é pertinente e tende a resposta a ser negativa, justamente pelo fato de que a apelação, nesse caso, somente retiraria o vício a maior do que o pedido, sem a necessidade de adentrar para julgar outros pontos. Somente retirar o vício do excesso de julgamento já é suficiente para a devida sanabilidade da demanda, sem a necessidade de qualquer outro julgamento de mérito.

\subsection{Omissão de um dos pedidos da inicial ou sentença citra petita}

Quando houver omissão em um dos pedidos da inicial, a interposição da apelação permitirá ao Tribunal a possibilidade de apreciá-lo, mesmo quando o juízo de primeiro grau atuou com desídia, deixando uma lacuna processual ao não responder em sua sentença todos os pedidos realizados pelo autor na petição inicial.

De certo modo, o Tribunal terá a permissão para analisar pela primeira vez tal matéria, o que impossibilita imaginar-se a configuração de uma devolutividade, pelo fato de que não houve uma impugnação de uma decisão, tampouco uma reanálise, mas o pedido para que se analise pela primeira vez aquele pedido que não foi enfrentado na sentença recorrida.

O efeito desobstrutivo, presente de modo geral na teoria da causa madura, nessa hipótese não estará presente, uma vez que não há um vício para ser desobstruído, mas somente uma omissão a ser sanada com uma ação, o que será realizado com o simples com o enfrentamento e julgamento do pedido outrora omisso ${ }^{21}$.

O autor - ou, por vezes, o réu - pode interpor embargos de declaração para sanar tal vício, contudo não há uma obrigatoriedade nessa via recursal, uma vez que a apelação tem ampla devolutividade material, possibilitando até a impugnação daquilo que não é

21 "Perceba-se que, neste caso (e partindo da premissa de que aquilo que foi julgado está correto, evidentemente), nada haverá a reformar ou anular, sendo o caso, tão somente, de integrar a decisão judicial.” CÂMARA, Freitas, A. (01/2017). O Novo Processo Civil Brasileiro, $3^{a}$ edição. [Minha Biblioteca]. Retirado de https://integrada.minhabiblioteca.com.br/\#/books/9788597009941/ 
conteúdo da sentença, como neste caso específico.

Então, o Tribunal pode, desde logo, julgar o mérito desse pedido ausente da sentença, aplicando a teoria da causa madura, pelo motivo do processo já estar apto para tal julgamento, tanto que os outros pedidos foram julgados e esse esquecido, gerando uma sentença citra petita ${ }^{22}$, sendo suprida pela possibilidade do colegiado já julgar tal ponto.

\subsection{A falta de fundamentação da sentença e o vício por não seguir o art. $489, \S 1^{\circ}$}

A última hipótese do art. $1.013, \S 3^{\circ}$ versa sobre a ausência de fundamentação da sentença, quando não se segue a forma especificada no art. $489, \S 1^{\circ}$, ou seja, não há uma fundamentação adequada na sentença, tornando-a desidiosa e lacunosa.

Notório é que as decisões judiciais devem ser fundamentadas, tanto na norma constitucional quanto na infraconstitucional, contudo o CPC/2015 propôs uma autêntica e inovadora "teoria geral da fundamentação de decisão judicial," disposta no art. $489, \S 1^{\circ}$ sobre paradigmas pontuais e formais que a decisão deve conter para entender-se como fundamentada $^{23}$. Não se entendeu pertinente criar um rol ou um manual de como se fundamentar uma decisão judicial, mas delineou-se pontos em que não considerar-se-á a decisão como fundamentada.

O que a norma apresentou foram apontamentos reprováveis em uma decisão judicial, sob pena de que se constante em tal decisão, tornar-se-á esta nula.

$\mathrm{O}$ rol de regras transversas sobre a fundamentação ${ }^{24}$, como já exposto, está prevista

22 “a sentença é citra petita, também chamada de infra petita, quando fica aquém do pedido do autor ou deixa de enfrentar e decidir causa de pedir ou alegação de defesa apresentada pelo réu No aspecto subjetivo é citra petita a decisão que não resolve a demanda para todos os sujeitos processuais." NEVES, Daniel Amorim Assumpção. Manual de direito processual civil. 8. ed. Volume único. Salvador: JusPodivm, 2016. p. 1.086/1.087.

23 “ $\mathrm{O} \S 1^{\circ}$ com certeza é inovação digna de nota, pois diz que a garantia da fundamentação das decisões judiciais, de índole constitucional, não se tem por satisfeita, se a fundamentação não atender a certos parâmetros de qualidade. Ou seja, não é qualquer fundamentação que satisfaz. Deve-se sublinhar que os dispositivos serão comentados em seguida dizem respeito não só à sentença, mas a quaisquer decisões judiciais. Quando se estuda motivação da decisão, na verdade, o que se estuda é o que aparece na decisão, que seria uma espécie de "fachada", mas mesmo assim, é interessante estudar este fenômeno, já que representa, pelo menos, o que é compreendido como satisfatório para figurar como fundamento da decisão, em face das exigências do dado sistema.". WAMBIER, Teresa Arruda Alvim; CONCEIÇÃO, Maria Lúcia Lins; RIBEIRO, Leonardo Ferres da Silva; MELLO, Rogério Licastro Torres de. Primeiros comentários ao novo código de processo civil. $1^{\mathrm{a}}$. Ed, São Paulo: RT. 2015. p. 793.

24 "Todas as possibilidades de configuração de fundamentação inexistente ou insuficiente previstas neste parágrafo convergem para duas situações genéricas: (i) generalidade ou "vazio" do texto constante da fundamentação, que abarca os incisos I, II, II, V e VI; (ii) falta de enfrentamento de todos os argumentos 
no art. 489, $\S 1^{\circ}$. O intuito do legislador passou por apontar os erros frequentes nas decisões judiciais ou os vícios pertinentes a esta atividade, com uma tentativa de aplacar-se tais práticas e melhorar a prestação jurisdicional. Com isso, o art. 489, § $1^{\circ}$ ganha uma dimensão imensa, com notória importância, como uma cartilha de fundamentação de uma decisão judicial.

De um modo geral, o CPC/2015 primou por uma fundamentação mais real e analítica em cada decisão judicial, impondo ao juízo na prolação de qualquer ato decisório a necessidade de responder todas as teses jurídicas levantadas pelas partes, fundamentando de maneira coerente com a jurisprudência, explicando de maneira clara os motivos da utilização da norma ou das decisões construídas pelo juízo, sem campos vazios ou simples indicação de normas ou jurisprudências, necessitando de explicitação da relação destas com o caso, numa real fundamentação.

Quando a apelação impugnar a sentença pelo fato de não haver a fundamentação correta e completa, o Tribunal ao acatar tal tese deve decretar a nulidade da decisão por ausência ou vício de fundamentação, com a possibilidade de adentrar-se, desde logo, no julgamento do mérito da questão ou do processo como um todo, analisando-o pela primeira vez, sem considerar a sentença prolatada e agora anulada, uma vez que não se almejará a reforma, mas um real novo julgamento ${ }^{25}$, uma vez que houve um vício formal na sentença, tornando-a nula.

\subsection{A hipótese do art. $1.013, \S 4^{\circ}$ : a reversão da sentença que reconhece a prescrição ou decadência}

Além das hipóteses elencadas acima e dispostos no art. 1.013, § $3^{\circ}$, outra vem logo a seguir, no art. 1.013, $\S 4^{\circ}$, quando uma apelação impugna uma sentença em que se reconheceu a decadência ou a prescrição e, na via recursal conseguiu-se o provimento para afastar qualquer destas prejudiciais, podendo se houver viabilidade processual para o julgamento meritório da demanda, desde logo, proferir o acórdão com o enfrentamento do

que poderiam contrariar a decisão tomada pelo juiz, situação prevista no inciso IV.” NERY JR, Nelson; NERY, Rosa Maria de Andrade. Código de Processo Civil Comentado. 16a . Ed. São Paulo. RT. 2016. p. 1248.

25 Enunciado n ${ }^{\circ} .307$ do FPPC: "Reconhecida a insuficiência da sua fundamentação, o tribunal decretará a nulidade da sentença e, preenchidos os pressupostos do $\S 30$ do art. 1.013, decidirá desde logo o mérito da causa. 
mérito.

Se o juízo de primeiro grau analisar a demanda, seja de modo preliminar durante a análise perfunctória para a inicial, seja somente depois das alegações pelo réu, e constatar a incidência de prescrição ou decadência do direito pleiteado na demanda deve já prolatar sentença, mediante a constatação de tal configuração impeditiva de chegar-se ao julgamento responsivo ao pedido constante da inicial. Em qualquer desses casos, se realmente houver tal incidência destes institutos, por força do próprio art. 487, $\mathrm{II}^{26}$ deve ser prolatada sentença de mérito, com a impossibilidade de apreciar o pedido pleiteado pelo autor, justamente pelo fato de que há prescrição ou decadência.

Diante de uma sentença com esse conteúdo, o intuito de eventual apelação do autor está em provar a não incidência de prescrição e decadência. Se obtiver êxito nessa argumentação, com o afastamento dessas matérias, o mérito da demanda, aquele pedido realizado pelo autor na inicial, volta a ter uma abertura cognitiva, com a possibilidade, se for o caso, de apreciação diretamente pelo Tribunal de segundo grau, caso não necessite de outras produções de provas ou argumentações das partes.

Todavia, somente será possível a aplicação da teoria da causa madura nessa hipótese - prescrição e decadência - caso não haja necessidade probatória sobre o pedido da demanda, sobre o mérito propriamente dito e, ainda, que o réu já tenha se manifestado na demanda, sem a possibilidade de que haja a teoria da causa madura quando tais institutos forem constatados na análise perfunctória da inicial.

Se houver qualquer possibilidade de produção de provas ou manifestação do réu, dado o provimento do apelo para afastar a prescrição e decadência, deve-se remeter os autos para o primeiro grau para a continuidade do procedimento nessa instância.

26 "Embora a decadência e a prescrição sejam consideradas pelo legislador pátrio como de mérito (art. 487, II), interditam a análise do mérito propriamente dito, e daí a designação de prejudiciais de mérito. Ora, se o tribunal considerar cabível o afastamento dessas prejudiciais, não deverá determinar o retorno dos autos do processo ao juízo de primeiro grau de jurisdição para nova sentença, cabendo à Corte, se possível, julgar o mérito propriamente dito.” NASCIMENTO NETTO, Marcos Aurélio. Comentário ao art. 1.013. Novo Código de Processo Civil Comentado - Tomo III. Orgs: RIBEIRO, Sergio Luiz Almeida; GOUVEIA FILHO, Roberto Pinheiro Campos; PANTALEÃO, Izabel Cristina; GOUVEIA, Lucio Grassi de. Ed. Lualri,São Paulo, 2017. p. 364. "Neste caso, incumbirá ao tribunal de segundo grau pronunciar-se, desde logo, sobre o restante do mérito (já que decadência e prescrição são questões que já integram o mérito, motivo que leva a falar-se, aqui, em exame do "restante do mérito")." CÂMARA, Freitas, A. (01/2017). O Novo Processo Civil Brasileiro, $3^{a}$ edição. [Minha Biblioteca]. Retirado de https://integrada.minhabiblioteca.com.br/\#/books/9788597009941/ 


\section{A TEORIA DA CAUSA MADURA COMO MEIO DE PRIMAZIA AO JULGAMENTO DE MÉRITO}

Ao imaginar uma codificação com um novo paradigma, com uma preferência e prioridade sistêmica de priorizar o julgamento de mérito, tornando-a a real atividade jurisdicional que detém importância, o legislador inaugura uma nova visão sobre a sistemática processual, dispondo a importância de realmente conceder uma prestação jurisdicional que responda a pretensão posta em juízo, de modo satisfativo às partes.

Com base nessas novas premissas, no decorrer de todo o CPC/2015, há uma prioridade ao julgamento de mérito, incluindo diversos momentos processuais foram imaginados como flexíveis para possibilidade uma prioridade ao julgamento de mérito, com a positivação de relativizações sobre o formalismo processual para esse nível e grau de profundidade do julgamento.

A base para este princípio está no art. $4^{\circ}$ do novel ordenamento processual, mediante a especificação de que há uma prioridade para a prestação jurisdicional satisfativa. Todavia, este princípio não está presente somente no art. $4^{\circ}$, mas espalhado e permeado por toda a codificação, como uma nova base paradigmática processual. Sempre que houver uma forquilha jurídica em algum momento do processo, quando for possível uma flexibilização formal, sem prejuízo para as partes, há de se escolher pela busca pelo julgamento do mérito, com o máximo aproveitamento processual e uma total relativização da formalidade, em prol de se propiciar a resolução do mérito em si.

Se o CPC/2015 é impactado por este princípio que prioriza o julgamento de mérito em vários momentos processuais, não seria diferente na fase recursal ${ }^{27}$, até pelo fato de que a maioria dos processos ultrapassam o primeiro grau, resolvendo-se na esfera dos Tribunais. Evidente que uma maior preocupação em transformar o caminho final processual no efetivo julgamento de mérito passa por aplicar a mesma tendência dogmática aos recursos.

27 Detalhadamente sobre o tema do princípio da primazia de mérito na esfera recursal: LEMOS, Vinicius Silva. O princípio da primazia de mérito na fase recursal de acordo com o Novo Código de Processo Civil. In: Fredie Didier Jr., Lucas Buril de Macêdo, Ravi Peixoto, Alexandre Freire. (Org.). COLEÇÃO NOVO CPC - DOUTRINA SELECIONADA - PROCESSO NOS TRIBUNAIS E MEIOS DE IMPUGNAÇÃO ÀS DECISÕES JUDICIAIS. 2aed.Salvador - BA: JusPODIVM, 2016, v. 6, p. 747-765. 
Dessa forma, o princípio da primazia do julgamento de mérito ${ }^{28}$ almeja, na esfera recursal, possibilitar mais julgamentos integrais dos pedidos recursais, priorizando a resolução do mérito que se busca na demanda via aquele recurso interposto, igualmente relativizando o formalismo para propiciar o julgamento real do que se impugna na forma recursal.

O intuito passa por aplacar o excesso de julgamentos recursais que não conseguem ultrapassar a admissibilidade, impossibilitando à análise do mérito. Essa é a forma, nesse momento processual recursal, que o princípio da primazia do julgamento do mérito se manifesta, dada prioridade em conceder a resposta do direito material ali almejado ou do pedido recursal realmente realizado.

Se no CPC/73 discutia-se na doutrina se a possibilidade de utilização da teoria da causa madura seria ou não uma forma inconstitucional pela supressão de instância, não possibilitando o juízo de primeiro grau sentenciar o mérito, tendo a parte somente o pronunciamento meritório diretamente do Tribunal e sem possibilidade de recurso com duplo grau de jurisdição, o CPC/2015 já o tem como um instituto basilar para alcançar o mérito e proporcionar eficiência à demanda, numa visão sistêmica de prioridade ao julgamento de mérito e a prestação jurisdicional mais célere.

$\mathrm{O}$ argumento da possível inconstitucionalidade era baseado na tese de um prejuízo processual para a parte que viesse a ser sucumbente na apelação que utilizou dessa teoria. No entanto, essa visão e questão é totalmente superada na doutrina e jurisprudência sobre a validade da teoria da causa madura, com a total possibilidade do CPC/2015 em ampliar a importância do instituto, corroborando e entrelaçando-o com o princípio da primazia ao julgamento de mérito.

\subsection{A teoria da causa madura e o recurso ordinário}

$\mathrm{O}$ art. $1.027, \S 2^{\circ}$, quando estipula regras sobre o recurso ordinário determina que este seguirá regras de outros dispositivos legais recursais existentes no recurso de

28 “Todas estas inovações são postas justamente para evitar que o processo siga um percurso inútil, baixando ao primeiro grau e retomando ao segundo, exatamente com o mesmo material cognoscitivo que já está à sua disposição." GUIMARÃES PESSOA, FLÁVIA M; ESMERALDO, A. M.. Teoria da Causa Madura e o duplo grau de jurisdição no novo código de processo civil. Revista Eletrônica de Direito Processual , v. 15, p. 195-2012, 2015. p. 210. 
apelação. Para tanto, na hipótese do art. 1.013, $\S 3^{\circ}$, justamente' no tocante ao que se dispõe sobre a teoria da causa madura, há uma viabilidade de intersecção entre o instituto e o recurso ordinário, demonstrando a positivação da sua aplicabilidade nesta espécie recursal.

A teoria da causa madura é uma busca pela economia processual na apelação e, pelo fato de que o recurso ordinário utiliza da tramitação e procedimentalidade inerentes a este recurso, essa possibilidade de ampliação do alcance da teoria da causa madura, consequentemente inclui a sua incidência no recurso ordinário, com total possibilidade de sua utilização nesta espécie recursal.

Essa possibilidade amplificada consiste numa positivação pela celeridade processual, imaginando a contemplação do direito material do jurisdicional, que, desde logo, pode contar com um julgamento de mérito, neste caso, quando for o momento do julgamento do recurso ordinário. Entre entendimentos conflitantes dos Tribunais superiores sobre a matéria sobre a utilização da teoria da causa madura nos recursos ordinários, escolheu-se legislativamente que esta inovação processual seja impactando e utilizável nesta espécie recursal, com a necessidade de uma adaptação dos Tribunais e das partes.

Mais uma semelhança entre o recurso ordinário e a apelação.

Nessa situação, a intenção está em aplicar a mesma amplitude dada ao recurso de apelação ao recurso ordinário, mediante a possibilidade de quaisquer dos Tribunais competentes ao julgamento do recurso ordinário utilizar da teoria, justamente quando deparar-se com situações processuais moldadas no art. $1.013, \S 3^{\circ}$ e após afastar o vício processual existente naquela demanda, poder adentrar no mérito da ação, julgando-o e decidindo a causa naquele momento.

Essa extensão da teoria da causa madura ao recurso ordinário demonstra que o ordenamento processual almejou ampliar a celeridade processual, sem idas e vindas do processo. Se é possível decidi-lo naquele momento, deve o Tribunal assim realizar, sem hesitar, prestando a jurisdição com economia processual, mesmo que seja num recurso ordinário. Essa foi a concepção dialógica entre os institutos da apelação e do recurso ordinário.

Desse modo, se o recurso ordinário segue a regra de tramitação da apelação, nada mais justo que esta amplificação da teoria da causa madura fosse lhe igualmente ampliada, possibilitando de igual maneira a mesma celeridade. Importante salientar que o recurso 
ordinário tem uma característica diversa dos demais recursos, pelo fato de impugnar em algumas possibilidades acórdãos de Tribunais que julgaram ações de competência originária, bem como também sentença em processos que tenham determinadas partes, como país ou entidade estrangeira versus município ou pessoa domiciliada no Brasil.

Em qualquer dessas possibilidades, cabe a teoria da causa madura no julgamento do recurso ordinário quando houver o enquadramento e oportunidade deste instituto processual.

\subsection{A teoria da causa madura no agravo de instrumento contra decisão parcial}

$\mathrm{O}$ art. $1.013, \S 3^{\circ}$ especifica a teoria da causa madura - o Tribunal entrar no julgamento de mérito mediante o provimento do recurso para anular a decisão recorrida no julgamento do recurso de apelação, mas há a possibilidade no CPC/2015, de modo positivado, sobre a prolação de uma decisão parcial, com ou sem mérito, sendo uma decisão interlocutória com um sentido de conteúdo idêntico à sentença, somente com a escolha pela prolação decisória de maneira bipartida, por caminhos processuais diversos, contudo com conteúdo baseado nos arts. 485 ou 487 em ambas as decisões - interlocutória ou sentença, somente com a diferença de que a sentença encerra uma fase e a interlocutória não, fora o fato sobre a recorribilidade, da sentença ser impugnada via apelação e a decisão parcial de via agravo de instrumento.

Se na impugnação da sentença cabe a teoria da causa madura, de igual forma, deve na impugnação da decisão parcial - via agravo de instrumento - caber a utilização da teoria da causa madura quando configurável os mesmos requisitos para a sua incidência.

Durante o julgamento do agravo de instrumento, se a decisão parcial for afastada por alguma das hipóteses elencadas pelo art. $1.013 \S 3^{\circ}$, o colegiado, desde logo, deve debruçar-se sobre aquela matéria meritória específica da parcela da demanda que outrora foi julgada, para dedicar-se ao novo julgamento, ainda que seja em grau em agravo de instrumento e somente sobre a parcela da demanda que está em recorribilidade no Tribunal, sem ser a completude da demanda.

A relação necessária - entre recurso e a decisão - deve ser o seu conteúdo, em ambos os casos, o mérito. Se cabe na apelação a teoria da causa madura, nas hipóteses correspondentes que versarem sobre a teoria da causa madura, de igual forma, devem ser 
passíveis de utilização em tal forma recursal sobre a decisão parcial.

\subsection{O princípio da proibição da reformatio in pejus e sua relativização na teoria da causa madura.}

Por este princípio, o ato de vontade que gera o protocolo de num pedido recursal não pode resultar para quem recorre em uma situação pior do que lhe foi imposta pela decisão sobre a qual recorreu. Não se pode pensar numa situação judicial em que o recurso traria pioras para a parte recorrente pelo seu próprio pedido, assim, plausível se torna a impossibilidade do julgamento recursal tornar a situação de quem recorreu pior do que a antes.

A ideia da possibilidade recursal nasce da chance de uma parte processual buscar a revisão da decisão para retirar a sucumbência que sofreu, almejando uma melhora, uma tentativa de extirpar o que perdeu. Não é congruente imaginar uma possibilidade em que o recurso de uma parte possa piorar a situação desta, o que se possível tornaria o ato recursal envolto muito mais de receios do que utilidade processual. $\mathrm{O}$ ato de recorrer seria imbuído de incertezas para o recorrente.

Se o ato recursal é a busca pela melhora em sua situação processual ou material, não há tal liberdade do juízo recursal para piorar a situação do recorrente. No CPC/39, existiam dúvidas sobre a possibilidade da reformatio in pejus ou sobre sua proibição, pelo art. 824 daquela codificação, que abria um leque de possibilidades para o Tribunal quando dispunha que "a apelação devolverá à superior instância o conhecimento integral das questões suscitadas", tendo pela interpretação da palavra integral a possibilidade de revisitar a matéria totalmente, sem vínculos aos pedidos recursais ou alguma delimitação. Todavia, impor ao recorrente a possibilidade de seu recurso trazer-lhes prejuízos é limitar o próprio direito de recorrer, causando de antemão, espanto e receio à parte recorrente.

Tal situação de impossibilidade de piora da situação do recorrente está bem estabelecida no ordenamento, tanto no revogado quanto na atual codificação, sem a possibilidade do recorrente em ver a piora em sua situação, com no mínimo a manutenção do seu status quo na demanda.

No entanto, é pertinente a indagação se a teoria da causa madura seria ou não uma possibilidade de reformatio in pejus? Nessa situação, com o constante do art. $1.013, \S 3^{\circ}$, 
caso haja uma sentença terminativa sobre a qual foi interposta uma apelação com alegação de error in procedendo na prolação da extinção, uma vez provido o apelo, há a possibilidade do julgamento adentrar no mérito da demanda, com o resultado pela improcedência da ação, se for o caso, para o autor, mesmo este sendo o recorrente, o que importaria em um prejuízo para quem recorreu.

Mas, essa situação seria a incidência de um reformatio in pejus? A leitura deve ser negativa, não sendo esta situação como uma configuração de real piora, somente o resultado do recurso não ser aquele desejado pela parte ao imaginar a possibilidade posterior do julgamento, via teoria da causa madura. O recurso foi exitoso no tocante à impugnação da sentença sem mérito, contudo no segundo momento decisório, há total liberdade para o julgamento do mérito da causa, com a possibilidade de ser de modo diverso de quem recorreu almejava.

Nesse caso, com o Tribunal utilizando a teoria da causa madura depois do provimento do apelo sobre a sentença de extinção, evidentemente que o julgamento do mérito é livre e, assim, se for improcedente pode causar um prejuízo a quem recorre, no caso o autor ${ }^{29}$. Todavia, essa utilização não será a mesma que a reformatio in pejus proibida pelo ordenamento e que enseja uma vedação ao julgamento recursal.

\section{CONSIDERAÇÕES FINAIS}

Com a sanção do CPC/2015, a processualística brasileira sofreu diversas alterações, seja para revogações, seja para incrementos na norma e nos institutos, como na teoria da causa madura, objeto deste estudo.

Nesse prisma, a teoria da causa madura, instituto implementado na década passada ainda no CPC/73, teve no novo ordenamento uma evolução processual, dentro de um pacote de medidas para gerar uma economia processual e celeridade na entrega da prestação jurisdicional. $\mathrm{O}$ instituto não foi somente mantido, mas bem ampliado na nova codificação, com um significativo aumento de sua importância, de suas hipóteses de

29 Neves entende essa situação com uma exceção ao reformatio in pejus, com a devida autorização, contudo não é a melhor solução jurídica, sendo possível o acontecimento processual, mas sem configurar um real reformatio in pejus: "autor piora a sua situação porque, diante de uma sentença terminativa, recebe no julgado de seu próprio recurso de apelação decisão de mérito de improcedência, que produzirá coisa julgada materialNEVES, Daniel Amorim Assumpção. Manual de direito processual civil. 8. ed. Volume único. Salvador: JusPodivm, 2016. p. 603. 
incidência e uma clara demonstração da escolha do legislador em preocupar-se com uma prestação jurisdicional mais atenta à celeridade, numa busca pela entrega de um julgamento de mérito mais rápido e eficiente.

As hipóteses de utilização da teoria da causa madura foram ampliadas na apelação, continuando o cabimento sobre o recurso que impugna sentença terminativa, como no CPC/73, no entanto, aumentou-se o leque para outras hipóteses, como na impugnação de decisão incongruente com o pedido da inicial (sentenças extra, ultra ou citra petita), ou na impugnação de decisão que considera como não fundamentada, quando a parte entender que não se enfrentou todos os argumentos das partes, o que pode-se decretar a nulidade da sentença e analisar, desde logo, o mérito da demanda.

Outra hipótese, desgarrada das demais em termos de texto legal, consiste na possibilidade de um recurso impugnar decisão que acatou prescrição ou decadência, se houver o provimento do recurso, há a possibilidade de julgar-se o mérito, ainda que o juízo de primeiro grau não o tenha feito, ao acatar o afastamento da prejudicial.

O intuito em todas as possibilidades de utilização da teoria da causa madura é a celeridade processual. Sem este instituto, o colegiado deveria julgar o recurso provido, retirando o vício existente que impossibilitava o julgamento de mérito, e, provavelmente, determinar a remessa para o juízo a quo, para a prolação de nova sentença, o que acarretaria a possibilidade de uma nova apelação e, um novo julgamento para o colegiado

A teoria da causa madura abre uma possibilidade de o Tribunal julgar, desde logo, o mérito do processo, se houver matéria somente de direito, após afastar o vício processual anteriormente existente. Com isso, um instituto que melhora a prestação jurisdicional.

Além da sua já propagada e ampliada utilização no recurso de apelação, houve o transporte para o recurso ordinário e para o agravo de instrumento que impugna decisão parcial, possibilitando uma melhor visualização deste instituto.

Uma grande inovação processual, com a permissão de maior e melhor autonomia de julgamento pelo colegiado enfrentando, desde logo, o mérito da questão.

\section{REFERÊNCIAS}

CÂMARA, Freitas, A. (01/2017). O Novo Processo Civil Brasileiro, $3^{a}$ edição. Retirado de https://integrada.minhabiblioteca.com.br/\#/books/9788597009941/ 
CUNHA, Leonardo José Carneiro da; DIDIER JR., Fredie. Curso de direito processual civil. Meios de impugnação às decisões judiciais e processo nos tribunais. $13^{\mathrm{a}}$ ed. Salvador: JusPodivm, 2016.

DINAMARCO, Cândido Rangel. A reforma da reforma. São Paulo : Malheiros, 2002.

GUIMARÃES PESSOA, Flávia M; ESMERALDO, A. M. Teoria da Causa Madura e o duplo grau de jurisdição no novo código de processo civil. Revista Eletrônica de Direito Processual , v. 15, p. 195-2012, 2015.

LEMOS, Vinicius Silva. O princípio da primazia de mérito na fase recursal de acordo com o Novo Código de Processo Civil. In: Fredie Didier Jr., Lucas Buril de Macêdo, Ravi Peixoto, Alexandre Freire. (Org.). COLEÇÃO NOVO CPC - DOUTRINA SELECIONADA - PROCESSO NOS TRIBUNAIS E MEIOS DE IMPUGNAÇÃO ÀS DECISÕES JUDICIAIS. $2^{\mathrm{a}}$ ed. Salvador - BA: JusPODIVM, 2016, v. 6, p. 747-765.

LOPES Jr.. Gervásio. Julgamento direto do mérito na instância recursal. Salvador: Editora Jus Podivm, 2007.

JÚDICE, Monica. Comentário ao art. 1.013. STRECK, Lenio. (3/2016). Comentários ao código de Processo Civil, $11^{a}$ edição. Retirado de https://integrada.minhabiblioteca.com.br/\#/books/9788502635609/

MEDINA, José Miguel Garcia. Aspectos Polêmicos e Atuais dos Recursos e outros meios de impugnação às decisões judiciais, Editora Revista dos Tribunais, São Paulo, 2002.

MEDINA, José Miguel Garcia. Novo código de processo civil comentado. $2^{\mathrm{a}}$ Edição. RT: São Paulo. 2015.

MOREIRA, José Carlos Barbosa. Comentários ao Código de Processo Civil. $16{ }^{\text {a }}$ Rio de Janeiro: Forense 2011.

NASCIMENTO NETTO, Marcos Aurélio. Comentário ao art. 1.013. Novo Código de Processo Civil Comentado - Tomo III. Orgs: RIBEIRO, Sergio Luiz Almeida; GOUVEIA FILHO, Roberto Pinheiro Campos; PANTALEÃO, Izabel Cristina; GOUVEIA, Lucio Grassi de. Ed. Lualri, São Paulo, 2017.

NEVES, Daniel Amorim Assumpção. Manual de direito processual civil. 8. ed. Volume único. Salvador: JusPodivm, 2016.

NERY JR, Nelson; NERY, Rosa Maria de Andrade. Código de Processo Civil Comentado. 16ª . Ed. São Paulo. RT. 2016.

OLIVEIRA, Pedro Miranda de. Novíssimo Sistema Recursal conforme o CPC/2015. 
Florianópolis: Conceito Editorial, 2015.

SIQUEIRA, Thiago Ferreira. A aplicação da "teoria da causa madura" em caso de nulidade da sentença por falta de fundamentação: um diálogo com Marco Antonio Perez de Oliveira. http://portalprocessual.com/a-aplicacao-da-teoria-da-causa-maduraem-caso-de-nulidade-da-sentenca-por-falta-de-fundamentacao-um-dialogo-com-marcoantonio-perez-de-oliveira/

THEODORO JR, Humberto. Curso de direito processual civil: teoria geral do direito processual civil e processo de conhecimento. Vol. I. 52. ed. Rio de Janeiro: Forense, 2011.

WAMBIER, Teresa Arruda Alvim; CONCEIÇÃO, Maria Lúcia Lins; RIBEIRO, Leonardo Ferres da Silva; MELLO, Rogério Licastro Torres de. Primeiros comentários ao novo código de processo civil. 1 ${ }^{\mathrm{a}}$. Ed, São Paulo: RT. 2015. p. 1.450. 